\title{
When prey is winik (person): the relationship between people, animals, and their Masters in Lacandon hunt
}

\author{
Alice Balsanelli
}

\begin{abstract}
:
The Lacandon Maya of Chiapas (Southern Mexico) conceive animals as subjects endowed with a soul (pixan) and agency. Therefore, they are considered to be 'persons' (winik) whose mode of living is analogous to the humans': they're socially organized, they work in their milpas, they perform rituals and worship their gods. The attribution of personhood to animals becomes an ethical problem during hunt, when the Lacandon hunter kills a prey considered to be a 'fellow man'. Consequently, the hunt needs to be ritually justified and takes the form of a contract established between the hunters, the animals and the entities who protect them - the gods, the animal masters. It will be shown how the extension of the concept of personhood to animals influences Lacandon hunting ceremonialism, and how the theories proposed by the 'Ontological Turn' allowed to shed light on the Northern Lacandon hunt.
\end{abstract}

Keywords: Lacandon Maya, hunt, personhood, animism, animal masters.

\begin{abstract}
Resumen:
CUANDO LA PRESA ES EL WINIK (GENTE): LA RELACIÓN ENTTRE HUMANOS, ANIMALES Y SUS DUEÑOS EN LA CACERÍA LACANDONA

Los lacandones de Chiapas (sureste de México) conciben a los animales como sujetos dotados del alma (pixan) y del poder de actuar. Por lo tanto son considerados 'personas' (winik) que viven de una manera análoga a la de los seres humanos: se organizan socialmente, trabajan en las milpas, celebran rituales $y$ veneran a sus deidades. Esta extensión de la condición humana a los animales se vuelve éticamente problemática durante la caza, cuando el cazador lacandón mata una presa, considerada como una 'persona'. Por consiguiente, se necesita justificar ritualmente la caza, lo que toma la forma de un contrato acordados entre los hombres, animales y las entidades que tutelan la fauna -los dioses y los dueños-. Se argumentará de qué manera la extensión de la condición humana a los animales influye sobre las prácticas cinegéticas lacandonas, y de qué modo las teorías propuestas por el 'Giro Ontológico' permitieron arrojar luz sobre la cacería entre los lacandones.
\end{abstract}

Palabras clave: Mayas lacandones, cacería, noción de persona, animismo, dueños.

Alice Balsanelli - Centro de Estudios Mayas, Instituto de Investigaciones Filológicas, UNAM, email: alice.balsanelli@yahoo.com

1Dps://orcid.org/0000-0002-4785-5554 


\section{Introduction: The True People}

In this paper, I examine Lacandon Maya conceptions of animals as persons, and the implications of the endowment of personhood to game in Lacandon hunt.

I've been doing fieldwork among Lacandon people since 2011, working mainly in two villages: Nahá and Metzabok, both located in the North-West region of the Lacandon forest, in the state of Chiapas, México. The main purpose of my current research is recovering traditional Lacandon hunting practices, analyzing them as a social and ritual complex (Balsanelli 2019; 2021).

The Lacandon constitute one of the smallest indigenous groups in the world with less than 1500 individuals. They call themselves Hach Winik, an ethnonym meaning 'the True People' (Figure 1), and they speak Hach Tach, 'the True Language', which belongs to the Yucatec Mayan linguistic group, and is closer to the Itza-Mayan language, especially Northern Lacandon (Cook 2019: 4). Their former religious system, their pantheon and the ritual complex presented numerous similarities with ancient Maya practices, as was noted by the first anthropologists who worked in the Lacandon forest in the early twentieth century, including Tozzer (1907), Baer and Baer (1950), Soustelle (1966), and Bruce (1971, 1974). The preservation of some ritual practices and deities of the Classic and Postclassic Maya religion was enabled by the geo-

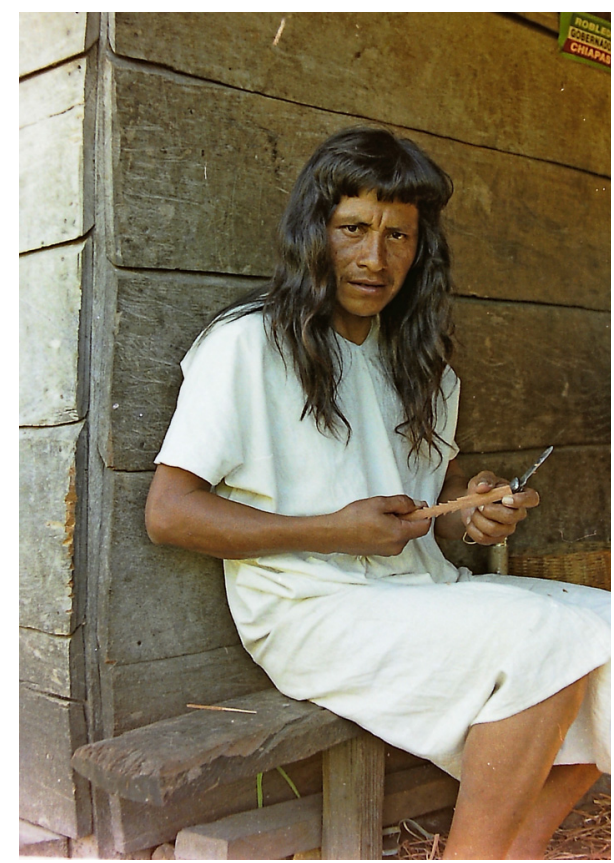

Picture 1: A Lacandon man crafting an arrow point in Nahá (Lluís Escartín Lara) graphic isolation of many Lacandon in the forest (see Tozzer 1907). Nevertheless, the rituals observed by the first scholars who worked among the Hach Winik represented a reminiscence of a more complex and structured ritual system: there were no priests or diviners, nor astronomers or mathematicians (Cook 2019: 14). The religious leaders were the male heads of the different families scattered in the forest, called toohil in Maya, a term originating from t'oh: 'just', 'wise' or 'great'. Each cluster of households was autonomous, and they worshipped specific deities, represented by a collection of incense burners (Figure 2). These sacred censers were kept inside the temple, a simple structure of pole and thatch, called u Yatoch K'uh ('the House of Gods'). Rituals involved the offering of copal incense and ba'alché (tree bark fermented with honey) to the god-pots (incense burners representing the Lacandon 
gods) and were performed in specific moments of the year, in accordance with the agricultural cycle or whenever the mediation of gods was needed: to ask for rain or to hunt, to help crops growth, or to initiate youngsters to adulthood. Moreover, the Lacandon believed that all diseases and accidents had a mystical cause (Boremanse 2020: 25). Sicknesses, misfortunes and miscarriages were thought to be provoked by an angry god to punish a person who had committed a wrong doing. Hence, rituals were also performed to placate gods and ask them to heal the culprit. Obviously, this conception of sicknesses changed when the Lacandon started contracting contagious diseases of Western origin.

In the twentieth century, the Lacandon started keeping frequent contacts and trade with people living outside their area, including visits by foreign anthro-

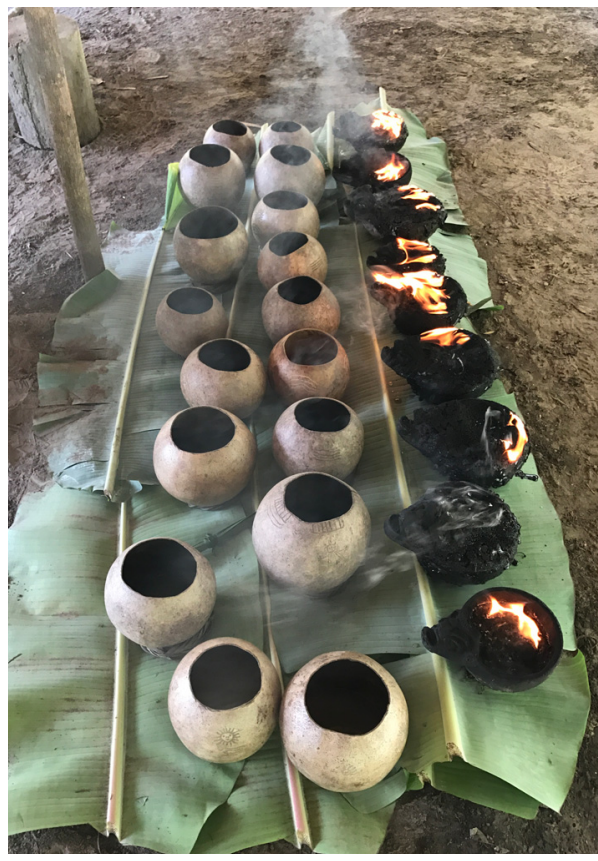

Picture 2: Bảalché and copal offered to the god-pots in the sacred temple, Nahá (Alice Balsanelli) pologists and scholars. At that time, they still venerated the ancient Maya ruins, in particular those of Palenque and Yaxchilán, to which they used to make frequent pilgrimages, for they were considered to be the houses of their heavenly gods. The Hach Winik managed to maintain their religion thanks to their geographical isolation until the Lacandon forest colonization began. In 1940, after the Mexican government designated the tropical lowlands of northeastern Chiapas as a national territory, colonists belonging to the Tzeltal and Chol groups started establishing settlements in the area, causing rapid deforestation, and forcing the Hach Winik to migrate and move constantly in search of new lands. After a few years, the small Lacandon settlements were surrounded by extensive colonies, and they abandoned the pattern of dispersion to gather in villages. At that point, they had repeatedly come in contact with the representatives of Christian and Evangelic religions, who tried to convert them. Conversions still take place in Lacandon communities, consequently the culture suffers drastic changes: rituals have fallen into disuse, the rites of passage and of marriage and the ba'alché ceremonies are no longer performed. The last active temple is located in Nahá, where the last toohil, don Antonio Chan K'in, sporadically leads ba'alché ceremonies, sometimes performed for tourists.

The Lacandon still practice slash-and-burn agriculture; in their fields, or milpas (kor, in Maya), they grow corn, black beans, chili peppers, squash, along 


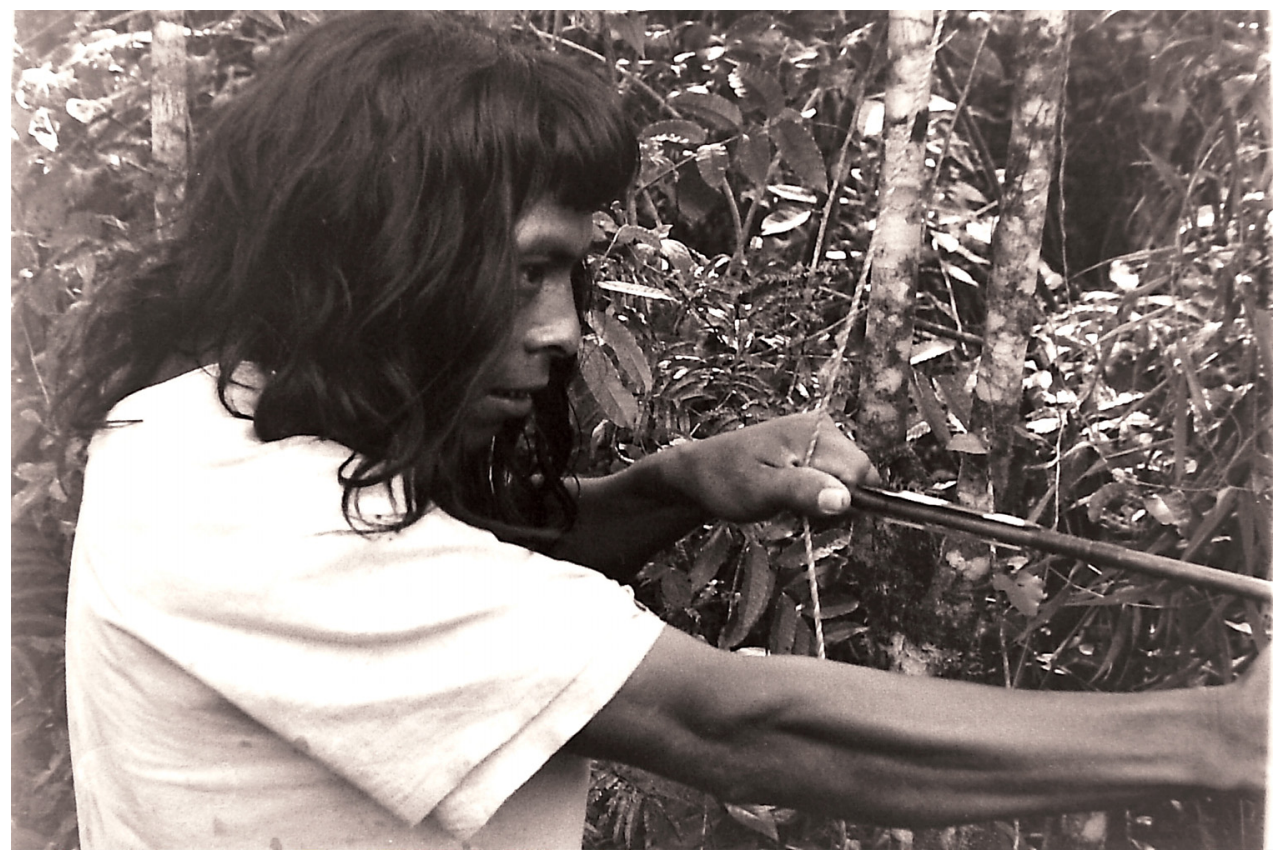

Picture 3: A Lacandon man hunting with a bow and arrows in Metzabok (Lluís Escartín Lara)

with different kinds of edible tubers and fruit trees, like mangoes, papayas, bananas, tangerines and lemons. Agriculture is still the most important source of sustenance. In the past, also the meat of the game obtained by hunting in the forest was an important source of food, as observed by anthropologists who worked among the Hach Winik in the mid-twentieth century (Figure 3). However, the area they inhabit was designated a Natural Reserve, as a result of the massive colonization of the Lacandon forest by Tzeltal Maya mentioned above (see Boremanse 2020:5). Therefore, hunting, once considered a primary form of sustenance and a sacred activity, was forbidden and it lost its social and ritual importance. For this reason, one of the purposes of my work is recovering the ancient hunting practices, through extended and intensive fieldwork, gathering the testimony of the last elders who in the past took part in the hunting parties and still remember the rules and taboos involved in hunting ceremonialism.

\section{Animism and perspectivism in Lacandon cosmos}

The theories of Ontology and Perspectivism have provided me with a framework for understanding the ontological principles on which Lacandon personhood is based, which was the main subject of my early works. As in many Amerindian groups, their ontology can be identified as 'animism', as defined by Descola (2012), 
for they conceive of the world as inhabited by different types of subjects, all of them sharing a common spiritual essence, called pixan in Lacandon Maya, which scholars translate as 'soul' or 'spirit'. Descola (2012: 193-199) defines animism as a social continuity between nature and culture, which is founded on the attribution of human characteristics and dispositions to a wider group of natural creatures and 'supernatural' phenomena. Thus, the concept of 'humanity' is the "original common condition" possessed by all natural beings (Viveiros de Castro 1998: 472; Vilaça 2014: 325). Actually, among the many contributions of the Ontological Turn, a critique of the classic Nature-Culture dichotomy stands out, pointing out that it cannot be used to describe cultural systems internal to non-Western cosmologies:

Such a critique, in the present case, implies a redistribution of the predicates subsumed within the two paradigmatic sets that traditionally oppose one another under the headings of 'Nature' and 'Culture': universal and particular, objective and subjective, physical and social, fact and value, the given and the instituted [...] body and mind, animality and humanity, among many more (Viveiros de Castro 1998: 469-470).

This article will mainly deal with the dichotomy animality-humanity, two categories that, in Amerindian cosmologies, appear to be a matter of different points of view, as it is suggested by the theory of perspectivism developed by Viveiros de Castro: "The available ethnographic evidence suggests that Amerindian cosmologies do not harbor a general, collective concept of 'animal' as opposed to 'human'. Humans are species among others, and sometimes the differences internal to humanity are on a par with species-specific ones" (Viveiros de Castro, 2007: 164). In sum, animals perceive themselves as humans when they are in their own collectives (socially organized groups), while humans see them as wild creatures or prey. Hence, the concept of 'animality' refers to the external form of these beings, and to the way they are perceived or seen by the members of other collectives. On the other hand, the internal form is the 'soul' or 'spirit', and "an intentionality or subjectivity formally identical to human consciousness, materializable, let us say in a human bodily schema concealed behind an animal mask" (Viveiros de Castro 1998: 471).

The same assumption can be found in Maya cosmology: all beings participate in an 'animated cosmos' built upon a complex net of relations where humans, deities, spirits, animals and plants constantly interact (Estrada, 2009: 198). Actually, while classical anthropology has always studied the 'alterity' in terms of 'human alterity', analyzing the modes of exchange among human societies or groups, the study of Amerindian cosmologies suggests that the native alterity encompasses a broader range of beings (Descola 2012; Cayón, 2012; Århem 2001, Vilaça 2014 among others):

Traditionally, and to a great extent still, (the Maya) they regard animals as fellow members of a wider society. In Maya religion, animals have a status as spiritual 
beings and as social persons - not human persons, but persons nonetheless. They communicate with humans and share with them a conscious participation in a sacred cosmos (Anderson, Tzuc 2005: xi).

In concepts of the Hach Winik, humans, animals, plants, natural objects and non-human entities such as the gods and the spirits living in the forest - possess the same spiritual essence, or 'soul' (pixan). Hence, they are all regarded as persons (winik) in essence. The term winik refers to the original and common condition of all the beings inhabiting the Lacandon cosmos: a peccary and a Lacandon man are said to be intrinsically identical, while the body marks the ontological difference, which reminds us of the question of Amerindian corporality, discussed by the authors of the Ontological Turn (Viveiros de Castro 2010; Descola 2012; Vilaça 2002 among others).

Lacandon people claim that in the forest wild animals live in collectives organized along the same lines as human society: they live in huts supported by wooden poles, they grow corn in their fields (milpas), and they possess temples where they worship their gods, they perform rituals and drink ba'alché. Within their collective, animals perceive themselves as people, and consider the Lacandon as predators. The model of 'perspectivism' or 'multinaturalism' was developed by Viveiros de Castro, referring to the presupposition that each living species is human within its own collective and possesses a specific point of view, localized in the body. This idea originates in indigenous cosmogonies, where the primordial form of the cosmos' creatures is human. Thus, the different types of beings that populate the world are transformations of this primordial humanity (Viveiros de Castro, 2010: 478); actually, a Lacandon would say that, from his point of view, a peccary is an animal who steals his maize and damages his crops, while in reality the peccary perceives himself as a person who is working in his own milpa, consuming the maize he has grown. A consultant from Nahá expresses this concepts in her own words: "Animals know that we are people too, we're all persons, even if we look different. The animal that steals our maize thinks that he's working in his milpa, that he's eating his maize" (Mrs. Koh, Nahá, personal communication, 14/07/2013).

The Lacandon consultants describe animals' collectives as societies organized just like the humans', let's see an example:

The wild boars lives just like us [...] Our ancestors saw it, they were hunters. They didn't have guns, they used only bows and arrows. My grandma's uncle told me that [one day] he was walking with his companions, they were carrying their arrows, when they heard a noise. First, they saw a group of wild boars, but then they looked again, and they saw people building their huts: children, women, men, they were all working together. So, my ancestor realized that he was watching the wild boars' village. He said to his companions: "we can't shoot our arrows! We can't kill them! See? They're people, just like us! They are alive, they are just like us" (Chan Bor E., Nahá, personal communication, 26/07/2013). 
Furthermore, what people see as lakes and rivers is the realm of aquatic creatures, which is identical to the space inhabited by the Lacandons. The informants claim that, under the surface of the lagoons, crocodiles, fishes and turtles live 'just like people' and perceive themselves as human beings. As we can notice, perspectival notions form an essential part of Lacandon animism:

Our ancestors could see the people who live under the water [...] my grandpa told me that, under the water, it's just like here: there are trees, huts, plants, everything that we have up here. Turtles are the grannies, and under the water they're just like women, they work in the kitchens and take care of the children; crocodiles and fishes are people too. We just see water, but they see it differently, they see a place similar to the one we're living in (Koh, Nahá, personal communication 14/07/2013).

Another example of 'Lacandon perspectivism' can be observed when informants describe the baalché rituals performed by animals: it is said that frogs and toads gather to drink the sacred liquor for the god of rain (Mensäbäk), when people hear frogs 'singing at night', it is because they're celebrating a feast, their ceremonial drink is mud, but they see it as real baalché. The same occurs inside caves where bats (tsek, in Mayan) prepare tamales, ba'alché and burn copal for their gods. If a man enters a cave, he would be invited to participate in the feast, the toohil (the wise one) who leads the ceremony would offer the human tamales and meat to eat, but the latter would only see fruits.

As was noted by Viveiros de Castro, studying numerous references in Amazonian ethnography, perspectivism usually involves only some specific species of animals, such as the main predators and the principal game (1998: 471). Nevertheless, according to my field data, Lacandon people tend to conceive of all the animals as winik, including small insects, such as bees and ants, even if in their cosmology some species are considered more important: the principal predators (the jaguar) and the main prey animals (deer, peccary, spider monkeys, howler monkeys), which are constantly mentioned in the local legends and in the informants' discourse.

Under normal conditions, humans are not able to see wild animals as persons (which should be their real form), but myths relate that, in ancient times, the Lacandon were blessed with a 'divine sight', that allowed them to see all the creatures of the forest as people and to communicate with them. After losing that gift by divine punishment, men lost the capability of seeing the villages of the animals scattered in the jungle, they ceased to see trees under their human form, and to converse with the spirits and the minor gods living in the forest. Actually, Amerindian myths always take place at a time when the cosmos' entities shared a generic human condition and were thus able to communicate with one another, as belonging to a wider 'human society'.

Thus, Lacandon myths and legends serve as a reminder for the future generations that, in reality, what they see as trees or prey animals are people instead, and 
the Hach Winik never forgot about it. On the other and, especially in the past, animals constituted an important element of the Lacandon diet, and this ambivalence in the identity of wild animals, considered at the same time as prey and persons, gives rise to an ethical problem. When the hunter finds himself in the position of a predator, he, in fact, kills a fellow man:

Animals are alive, they have pixan [soul, spirit], just like us; they suffer, they don't want to die. Poor animals! If we need to kill them, we must be careful, we must respect them: they shall not suffer, they must go quickly. We don't kill because it amuses us, we know that they are just like us. Poor animals! You can kill only if you need to eat, one animal or two, no more. You kill the animal, and you eat the meat, it's not a game, it's not funny. We need meat to feed ourselves, that's the only reason why we can kill. You take a life, the animal is so alive [ne kuxa'an], that's why you can't play. Hunt is sacred, because the permission is given by the gods (Kayum, Metzabok, personal communication, 2/12/2020).

It should be stressed that to underline the fact that animals are considered as 'persons', the consultant explains that they are endowed with a soul (pixan) and that they are 'alive' (kuxa'an). The term kuxa'an is extremely important, because its root ( $k$ 'uh, 'sacred' or 'divine') reminds us that, according to Lacandon people, life is considered sacred, a quality that is common to all the creatures living in the cosmos. Moreover, as I will explain later, the fact that animals and humans are considered as essentially identical, influences the behavior of hunters, who feel compassionate toward the prey because they understand that killing an animal involves an ethical problem.

Furthermore, animals are protected by non-human power entities, which belong to two categories. The first group is constituted by the earthly gods (see Boremanse 2020) who are thought to live inside caves in the jungle: K'änänk'ax (The Forest Keeper), Yahaw Nah (The Great House), and the Chembel K'uh (the Minor Gods). Moreover, each species is protected by the Animal Masters or Owners: there is a generic 'Master of Animals', called U Yum'il Bäk, and each social group is protected by a specific Master: the Master of Howler Monkeys (U Yum'il Maax), the Master of Peccaries (U Yum'il Kitam), the God of Vultures (u Kuh'i Ch'om), the Mother of Bees ( $U$ Na'il K'ab)), among others.

Their main responsibility is protecting the game from abusive hunters and to ensure that the hunters act correctly before, during and after the hunt, including respecting specific rules and taboos. The earthly gods and the animal Owners regard wild animals as their children ( $u$ tial), or as their domestic animals (u yärak). Hence, humans need to enter into a contract with these non-human entities in order to be allowed to hunt in the forest or to fish in the lakes. As an informant from Nahá points out: "We are killing their domestic animals, so we need their permission. If we don't ask them, we would be stealing, just like a man would steal my chickens. It would make me terribly upset" (Chank’in Cuarto, Nahá, personal communication). 
This notion can be observed in various Maya groups, where it is believed that the Animal Masters keep the wild animals in their farmyards. They allow them to leave only when a hunter asks for the permission to hunt through specific rituals and offerings (Thompson 1930; Villa Rojas 1992; Köhler 2007; Gabriel 2006).

Scholars who studied hunting ceremonialism in Amerindian groups underline that this practice represents a crucial moment of interaction between humans and non-humans, and it also allows us to understand the ontological notions of each group (Århem 2001; Descola 1996; Cayón 2012; Fausto 2002). Moreover, as Århem points out, all beings "participate in a field of social interaction defined in terms of predation and exchange" (1996: 186). As we will clarify, hunters need to behave correctly before, during and after hunt, because if they failed to fulfill their duties or to respect the prey, their position would change: from predators, they would become prey.

As I stressed, within native hunting societies, animals are regarded as persons, which implies an ethical problem, when a hunter chases and kills what, in essence, is a fellow human being. Thus, hunting needs to be legitimized by creating a social and ritual structure that takes the form of a contract between hunters and supernatural entities protecting the fauna. This logic fits perfectly into the Maya concept of 'natural space': a religious man knows that the totality of the natural domain is sacred, and it belongs to the gods who created it. Hence, in order to exploit any natural resource - by hunting or fishing, burning a portion of forest to make a field, chopping a tree to build a wooden boat - he needs to obtain the license of these non-human entities (Petrich 2007: 143). I will now describe the Lacandon hunting ritual complex, and the main rules and taboos involved.

\section{Killing a winik (person): notes on Lacandon hunt}

First of all, we can observe that hunting is regulated by specific ethical rules: a hunter shall kill only animals required to sustain his family, he can never exceed this amount. Hunting is never a sport or entertainment, for the man is aware that he is taking a 'person's life'. Therefore, killing is primarily justified by the need for food. Females and cubs must not be killed, only males. The prey must be killed neatly and quickly, and unnecessary pain shall not be inflicted. Finally, the meat must be consumed entirely, for waste is not allowed, and bones must be returned to Animal Masters.

Hunting was structured by three main ritual moments: the petition for prey in the sacred temple, the ritual preparation of the meat, and the return of animal remains in specific sacred shrines. Thus, when a hunter required meat to feed his family or to prepare offerings for gods, he had to plead for the permission of the deities; this process was carried out in the temple or in a cave, where one of the earthly god protecting the fauna was supposed to live. In both cases, copal was offered to 
the deity the hunter was addressing. The pleading recited by the hunter was similar to the prayers registered by Thompson (1930) among Guatemalan Maya: he asks for the permission to kill one or two animals, underlining that he will kill only the animals necessary for his sustenance. He also stresses the need to kill, justified by the necessity to eat and feed the gods. Finally, he promises that he will give something back to the gods if the hunt is successful:

Tza'ten in woch bäk, chen junturi in kinsik, cho' katur, m'in cheik u tutaj, k'in chik, in läj chik u bak', paachil, in ka tzeik tech, k'in botik'ech, in tzeik tech a woch waj, a woch bu'ul, a woch b'äk, in tokik pom, a ba'alché, tuworor...a chaik u joko, ti' in wilik, a chaik u tar, ti' in kinsik (Don Pancho, Nahá, personal communication, 15 May 2019).

Translation: "give me meat to eat, I will kill just one, just two, I won't let it rot, I will eat it, I will eat all the meat, then, I will give you [something] back, I will give you tortillas, beans, meat, I will burn copal, some ba'alché, everything... You'll allow them [the prey-animals] to show up, so that I would see them, I would kill them".

As any ritual process, hunting required a period of sexual abstinence (Thompson 1982: 217); a Lacandon man would not sleep with his wife the night before going to the forest, and he would avoid any contact with pregnant women. Moreover, a successful hunt required a special language, which might be called euphemistic: the intention of killing had to be masked, and no mention of violence or weapons was allowed. A Lacandon man would say to his wife: “Tomorrow I'll take a walk in the jungle", instead of expressing his intention to look for game. As Willerslev observes, in native hunting societies, men: "abandon ordinary speech in favor of a special linguistic code which skillfully screens out the reality of being a human predator" (2004: 642). Moreover, Lacandon people believe that animals, as they are winik, understand and speak Mayan, so, if they heard the hunter's intentions, they would anticipate him and hide in the woods. The informants explain that some prey animals are 'shaman-animals', capable of foretelling the future: the agouti (Dasyprocta Mexicana), the tepezcuintle (Cuniculus paca), the peccary, and the jaguar can perform the divination rite to anticipate the arrival of a hunter. These animals are called $U$ K'intik $u b \ddot{a}$ (literally 'They can foretell their own future'). If one of them hears the words of a hunter, he would perform the divination ritual to anticipate the predator and hide in the woods:

The tepezcuintle $u$ K'intik $u b a$ [foretells his future], if you want to kill it, you walk in the woods at night, you don't call its name, you don't say a word. You hunt on your own, or with a companion, but not too many people, only two. In the morning, you plan the hunt with your companion, the others don't know it, and you don't say anything, you only plan the day and the time, that's all. Because, if you speak, if you mention its name [of the prey] the tepezcuintle will know that 
you're coming for him, he will hear it, and he will hide. So, when you arrive to the mountain, animals won't show up and you won't be able to hunt (Carlos, Nahá, personal communication, 13/07/2013).

Hunters know that Animal Masters and earthly gods will punish them if they do not respect the established ethical injunctions. There are different kinds of punishments: the simplest one is to prevent the hunter from killing further prey; it's said that the Owners and gods won't allow game to show up when a cruel or abusive hunter goes to the forest. If the $\sin$ is considered more serious, the hunter can be punished with the loss of his soul, which leads to physical diseases, madness or even death. In some cases, the Masters can take the life of one of the hunter's relatives, as a form of compensation for the unauthorized or unfair killing of one of their protegees. Lacandon myths tell stories of some abusive hunters who were punished by the Masters after they behaved incorrectly (see Boremanse 2006); those tales are a reminder of the importance of respecting ethical rules, which are fundamental to maintain a good relationship between the human and non-human collectives. The situation we described underlines that respecting the rules becomes mandatory in a predatory cosmos: the hunter knows that, if he doesn't behave correctly, he would become a prey (see Århem 1996). So, just as the Lacandon hunter chases and kills his prey, the spirit of the animal or the Master can kill him by capturing or extracting his pixan:

If I kill too many animals, if I play with them and I don't eat the meat, if I don't respect their bones, the spirit of the animals will chase me. Maybe not now, not today, he can wait, he will follow me, he will seek his vengeance. Maybe he won't hurt me, but he can hurt my wife or my children but, for sure, he'll make me pay for my $\sin [$ siipil]. If someone lets an animal die in the forest, if he doesn't finish him and makes him suffer, if he's stupid and says: 'It's just an animal, and I am having fun, I killed for fun!", the spirit of the animal won't rest in peace until the hunter suffers too. Sometimes, they [the animals] can seek help among their yum 'il [Masters, lords]: the yum 'il will come, will kidnap the hunter, and will torture him, until he understands that he had done something wrong. This is what my grandpa told me. Would you let a person die in pain? Would you kill your brother for fun? No! The same happens with animals. They are winik, and we must respect them (Carlos, Nahá, personal communication, 13/07/2013).

After the hunter caught the desired prey, the preparation of the meat required a specific ritual process, especially when the meat filled the tamales for gods. Those offerings were called nahwah ('the great bread') and were offered in the temple to the gods who had allowed the hunt or to those whose intervention was needed. The same rules followed by hunters before killing the prey had to be respected by the women who prepared the sacred offerings. They had to observe a period of sexual abstinence and to isolate themselves in the household, avoiding any contact with men. The nahwah were prepared in the kitchen of the temple, where only 


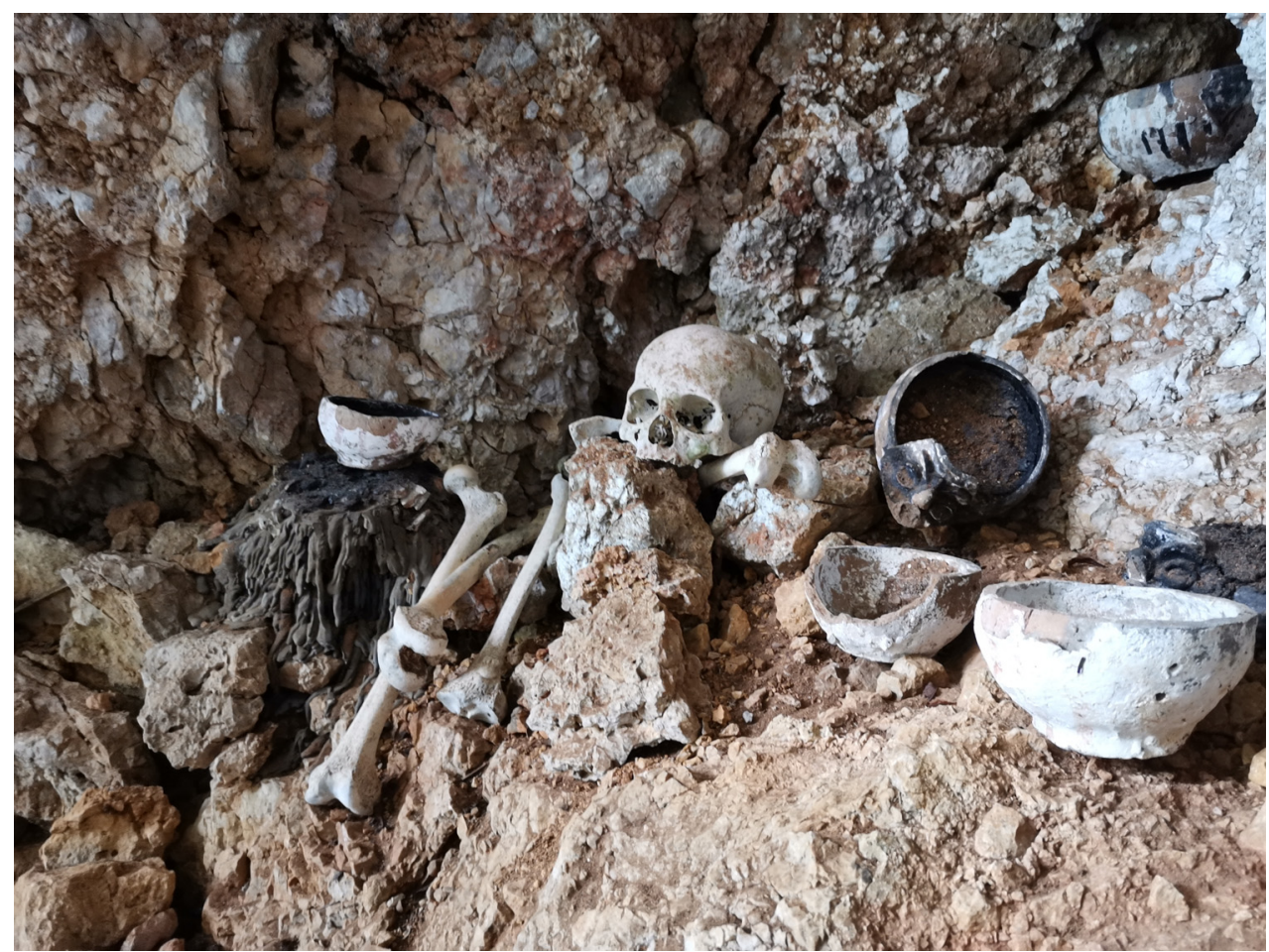

Picture 4: The sacred shrine in Metzabok where human bones and old censers were deposited (Alice Balsanelli)

women were allowed, which underlines that this activity was considered sacred (see Boremanse 2020:154-155). Before filling the corn dough with the game's meat, women had to wear clean clothes and to wash their hands, they were not allowed to try the food they were preparing, because the gods had to be the first ones to eat. They could not scratch their body or touch anyone while preparing the tamales, for the Lacandon believe that human smell would spoil the deities' food.

When the offerings were ready, the celebrant of the rite offered the tamales to the gods, small bits of meat and nahwah were placed inside the censers' mouths. The distribution of the offerings was accompanied by chants and copal was burnt (Boremanse 2020). Afterwards, people were allowed to share and consume the food.

The final moment of the hunting ritual complex consisted in the ritual deposition of the animal bones in the forest, to return them to the Animal Masters, who can regenerate the sacrificed creatures from their remains. The belief that animal remains must be subjected to a specific ritual deposition is observed in various Mesoamerican groups (Neurath 2008; Osorio-López et alii 2017; Dehouve 2008), and we can find numerous references to this practice in Amazonian societies (Århem 2001; Fausto 2002) and in other ethnographic contexts (Frazer 1944 [1890]; Lot- 
Falck 2018 [1953]; Hamayon 2009). Concerning Maya ethnography and archaeology, Brown (2005) studies contemporary and nineteenth-century Maya hunting shrines in the region of the Atitlan Lake (Guatemala highlands). As other authors who have worked on hunting ceremonialism, she stresses that returning the bones to the Animal Masters allows the rebirth of the hunted animals and assures the renewal of the hunters' divine license to hunt. This ritual was also observed among the Quintana Roo Maya (Santos-Fita, Naranjo et al. 2015), where the bones of the prey animals are cleaned and saved, and then returned to their Master, the Sip, during specific rituals, whose aim is the renewal of the permission to hunt and to show gratitude to the Animal Owner. In the beliefs of these native peoples, bones are considered as fertile elements, since

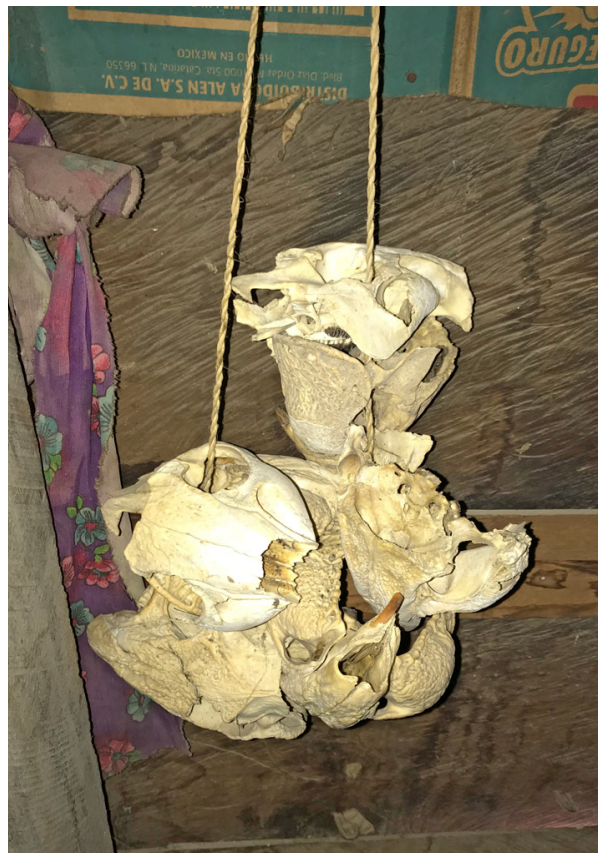

Picture 5: Skulls of prey animals preserved in a household, Nahá (Alice Balsanelli) they retain part of the spiritual essence of the subject they belong to. That is why Hamayon defines them as the 'soul support' (2009: 31-32). Similarly, the Maya regard bones as fertile elements, and they are consistently associated with elements belonging to the semantic field of vegetation and fertility, such as seeds, sprouts, and maize (Carlsen, Pretchel 1991: 26-28; Girard 1962: 156; Bassie-Sweet, Hopkins 2018: 80; Scherer 2015: 95; McAnany 2013: 46-47), which is why to describe the ritual deposit of bones in hunting shrines, Brown employs the suggestive metaphor "planting the bones" (2005).

Considering that bones are supposed to retain part of the spiritual forces of animals, they must be returned to their Owners, the intermediaries who will form new creatures from that vital hint contained in the remains (see Braakhuis 2001). Hunters who fail to return the bones of the prey commit a wrongdoing, since they do not allow the regeneration of the creatures they have killed. Thus, they will be punished by the Masters or by the animals themselves. Actually, one informant in Nahá told me that if a prey's bones are not properly stored up in the roofs of households, and if they are not returned to the forest, the spirit of the animal would chase the hunter who would find himself in the position of prey, causing illnesses or death, and, in some cases, the death of some close relative of the culprit (Carlos, Nahá, personal communication). In the past, Lacandon people stored the animal remains in the households or in the temple. Alternatively, some bones were deposited in the 
forest, in hollow tree trunks or in caves. Around the lake in Metzabok there are still many sacred shrines, where people deposited old censers, human bones and, according to the field data, the remains of some prey (Figure 4).

At present, since hunting has lost its importance, ritual depositing of animal bones is no longer practiced. Nonetheless, the remains are never wasted or burnt, which is still considered a sin and an insult towards the animals and their protectors. The bones are preserved in the kitchen or in other spaces of the house (Figure 5). Despite changes in their religion, the Lacandon still believe in the existence of the Animal Owners and they still regard animals as sentient beings with a soul and as winik (people).

\section{Conclusions}

Various anthropologists who worked among the Lacandon in the past underlined the importance of hunting for the Hach Winik, although it was only described as one of the principal means of sustenance, along with agriculture, and it was never studied from a religious or ritual point of view. In ethnographies, we can find descriptions of the Lacandon forest and its non-human inhabitants from a scientific point of view: the characteristics of the soil, the vegetation, the flora, and the fauna. Those descriptions are grounded in the Western conception of the forest conceived as a natural environment inhabited by wild creatures, and the antithesis to the world of men and culture.

The Ontological Turn developed an anthropological theory which obliged us to reshuffle our conceptual schemes, allowing us to analyze subjects of our studies from a different point of view. Through a comparison with the ethnographic data gathered by the authors of the Ontological Turn, I got the chance to highlight similarities and differences between various native hunting societies living in a similar environment: the forest. The selva, which belongs to the realm of 'Nature' in Western societies, representing a hostile environment, opposite to the concept of 'civilization' and Culture, is considered by the indigenous American cultures as a huge living creature, endowed with a soul, where all beings - also endowed with the sacred spiritual essence - participate in a network of social interactions. The forest, 'la nature domestique', as Descola would call it, is the place where humans constantly communicate and interact with other beings: they establish pacts of alliance, they can be allies or foes at the same time, they hunt each other, they cooperate and interchange goods and energies. Before studying Lacandon hunt or any other local ritual process, I needed to clarify the ontological notions possessed by this ethnic group: first of all, it was important to shed light on their concept of personhood, which represented the initial stimulus for the reflections on Lacandon hunt. This main subject was analyzed in the framework of the animistic notions possessed by the Lacandon group. Actually, it would be impossible to elucidate the relationship 
existing between hunters, their prey and the supernatural entities involved in hunting ritual complex without understanding that the Western dichotomy animalityhumanity is absent among the Lacandon.

In this paper, I emphasized that animals are regarded as 'persons' because in the Lacandon cosmos all beings are undifferentiated in their essential aspects: they possess the same spiritual essence (the pixan), they are socially organized, they are endowed with agency, rationality, and other human attributes. Hence, animals cannot be considered as a simple 'source of food' at the humans' disposal. In this context, hunt - which implies violence and predation - needs to be ritually and socially justified. As I argued, a hunter must maintain a correct behavior during each phase of hunting, which is considered a religious and sacred process.

Subsequently, I studied the Lacandon concept of alterity: the extended idea of 'personhood' creates a complex net of relations in which all beings, considered subjects, participate in a complex field of social interactions. In this context, hunt represents a fundamental moment of interaction between humans, spirits and animals. The Lacandon hunter needs to make a contract with the Animal Masters and the deities who protect the wild fauna, in order to obtain the license to kill one of their 'children' or 'domestic animals'. This pact involves following specific ethical rules, regulates the behavior of the hunter and defines the ritual moments constituting the hunting ritual complex. As Thompson observed (1982), Maya religion is founded on a contract established between humans and 'supernatural' instances. Hunting is a crucial moment of interaction between members of these two collectives, and respect for rules and taboos is fundamental in order to maintain a good relationship between humans and their creators and, finally, to maintain the cosmic order.

Nowadays, the Lacandon live in a Natural Reservation (Reserva de Flora y Fauna Nahá-Metzabok), where hunting is forbidden by law. Yet, we realize that past Lacandon hunting ceremonialism implied observing specific rules, constituting a system in which the main purpose (predation) was justified by a ritual and social complex. The extension of 'personhood' to animals and to other inhabitants of the forest compelled people to respect these rules before they were impacted by foreign laws. The existence of the Masters rules limiting the activity to subsistence hunting, and the restrictions on killing female animals were mechanisms of control of human activities in the natural environment, effectively regulating human behavior in the forest. 


\section{References}

Anderson, Eugene N., and Félix Tzuc, M.

2005 Animals and the Maya in Southeast Mexico. The University of Arizona Press, Tucson. Århem, Kaj

1996 The cosmic food web, Human-nature relatedness in the Northwest Amazon. In Nature and Society, edited by Descola, Philippe and Pálsson, Gísli, pp. 186-204. Routledge, London and New York.

Århem, Kaj

2001 Ecocosmología y chamanismo en el amazonas: variaciones sobre un tema. Revista Colombiana de Antropología 37: 268-288.

Baer, Philip, and Mary Baer

1950 Lacandon Ethnographic Material: Microfilm Collection of Manuscripts on Middle American Cultural Anthropology, XXXIV. University of Chicago Library, Chicago.

Balsanelli, Alice

2019 Cuando la comida tiene alma, ensayo sobre la cacería lacandona. Maguaré 1(33): 47-73.

Balsanelli, Alice

2021 "Quemar huesos es cosa del demonio": la prohibición de quemar los restos óseos de las presas entre los lacandones del norte. EntreDiversidades, Revista de Ciencias Sociales y Humanidades 8(2): 30-55.

Bassie-Sweet, Karen, and Nicholas Hopkins

2018 Maya Narrative Arts. University Press of Colorado, Louisville.

Boremanse, Didier

2006 Cuentos y Mitologías de los Lacandones. Contribución al estudio de la tradición oral maya. Guatemala. Academia de Geografía e Historia de Guatemala, Guatemala.

2020 Ruins, Caves, Gods \& Incense burners, Northern Lacandon Maya Myths and Rituals. University of Utah Press, Salt Lake City.

Braakhuis, Edwin

2001 The Way of All Flesh, Sexual implications of Mayan Hunt. Anthropos 96: 391-409.

Brown, Linda A.

2005 Planting the bones: hunting ceremonialism at contemporary and nineteenth century shrines in the Guatemalan highlands. Latin American Antiquity 16(2):131-146.

Bruce, Roberto

1971 Los Lacandones 2: Cosmovisión Maya, proyecto de Estudios Antropológicos del Sureste. Instituto Nacional de Antropología e Historia, Mexico.

Bruce, Roberto

1974 El Libro de Chan Kin. Instituto Nacional de Antropología e Historia, Mexico.

Carlsen, Robert S., and Prechtel Martin

1991 The flowering of the dead: an interpretation of Highland Maya culture. Man 6: 23-42. Cayón, Luis

2012 Gente que come gente: a propósito del canibalismo, la caza y la guerra en la Amazonía. Maguaré, 26(2): 19-49.

Cook, Suzanne

2019 Xurt'an, the end of the world and other myths, songs, charms and chants by the Northern Lacandones of Nahá. University of Nebraska Press, Lincoln. 
Dehouve, Danièle

2008 El venado, el maíz y el sacrificado. Diario de Campo, Cuadernos de Etnología 4: 1-39. Descola, Philippe

1996 La Selva Culta, Simbolismo y praxis en la ecología de los Achuar. ABYA-YALA, Quito. Descola, Philippe

2012 Más allá de naturaleza y cultura. Amorrortu Editores, Buenos Aires.

Estrada O., Adriana C.

2009 Naturaleza, cultura e identidad. Reflexiones desde la tradición oral maya contemporánea. Estudios de Cultura Maya XXXIV:181-201.

Fausto, Carlo

2002 Banquete de gente: comensalidade e canibalismo na Amazonia. Mana, 8(2): 7-44.

Frazer, James

1944 [1890]. La Rama Dorada, Magia y religión. Fondo de Cultura Económica,

Mexico-Madrid-Buenos Aires.

Gabriel, Marianne

2006 "Sib-ten a w-áalak'o’ob" ('regálanos tus hijos, tus criados'). Oraciones dirigidas al 'Protector de los Animales' (Sip)”. In Sacred Books, Sacred Languages: two thousand years of Ritual and religious Maya literature, coordinated by Valencia Rivera, Rogelio, and Geneviève LeFort, pp. 93-111. Acta Mesoaméricana 18, Verlag Anton Saurwein, Germany.

Girard, Rafael

1962 Los Mayas eternos. Mex Editores, Mexico City.

Hamayon, Roberte

2009 Chamanismo de ayer y hoy, seis ensayos de etnografía e historia siberiana: Selección de textos y coordinación de la traducción Roberto Martínez y Natalia Gabayet. Universidad Nacional Autónoma de México, Mexico City.

Köhler, Ulrich

2007 Los dioses de los cerros entre los tzotziles en su contexto interétnico. Estudios de Cultura Maya XXX: 139-152.

Lot-Falck, Éveline

2018 [1953] I riti di caccia dei popoli siberiani. Adelphi, Milan.

McAnany, Patricia

2013 Living with the Ancestors: Kinship and Kingship in Ancient Maya Society. Cambridge University Press, Cambridge.

Neurath, Johannes

2008 Cacería ritual y sacrificios huicholes: entre depredación y alianza, intercambio e identificación. Journal de la Société des Américanistes 94(1): 251-283.

Osorio-López, Dulce, Ramón Mariaca M., Dídac Santos-Fita, et al.

2017 Cacería y Cosmovisión en una comunidad ayuuk en San José el Paraíso, Oaxaca, México. Revista Etnobiologia 15(3): 54-66.

Petrich, Perla

2007 El espacio sagrado entre los mayas del lago Atitlán. Estudios de Cultura Maya XXIX:141-153.

Santos-Fita, Dídac, Eduardo J. Naranjo et al.

2015 Symbolism and ritual practices related to hunting in Maya communities from central Quintana Roo, Mexico. Journal of Ethnobiology and Ethnomedicine 11(71): 1-13. 
Scherer, Andrew K.

2015 Mortuary Landscapes of the Classic Maya: Rituals of Body and Soul. University of Texas Press, Austin.

Soustelle, Georgette

1966 Catalogues du Musée de L’Homme. Serie H, Amérique III, Collections Lacandons. Muséum National D’Historie Naturelle, Paris.

Thompson J., Eric S.

1930 Ethnology of the Mayas of Southern and Central British Honduras. Chicago: Field Museum of Natural History, Chicago.

1982 Historia y Religión de los Mayas. Siglo Veintiuno Editores, Mexco City.

Tozzer, Alfred

1907 A comparative study of the Mayas and the Lacandones. Mc. Millan Co., New York.

Vilaça, Aparecida

2002 Making kin out of others in Amazonia. Journal of the Royal Anthropological Institute 8: 347-365.

2014 Culture and Self The Different 'Gifts' Amerindians Receive from Catholics and Evangelicals. Current Anthropology 55(10): 322-332.

Villa Rojas, Alfonso

1992 Los Elegidos de Dios, Etnografía de los mayas de Quintana Roo. Instituto Nacional Indigenista, Mexico.

Viveiros de Castro, Eduardo

1998 Cosmological Deixis and Amerindian Perspectivism. The Journal of the Royal Anthropological Institute 4(3):469- 488.

2007 The crystal forest: notes on the ontology of Amazonian spirits. Inner Asia 9(2):153172.

2010 Metafísicas caníbales, Líneas de antropología postestructural. Katz Editores, Buenos Aires.

Willerslev, Rane

2004 Not Animal, Not Not-Animal: Hunting, Imitation and Empathetic Knowledge among the Siberian Yukaghirs. The Journal of the Royal Anthropological Institute 10 (3): 629-652. 